\title{
A Magyar Regionális Tudományi Társaság programja a 2012-2015 közötti időszakra
}

\section{Programme of Hungarian Regional Science Association between 2012-2015}

\author{
RECHNITZER JÁNOS, RÁCZ SZILÁRD
}

A Magyar Regionális Tudományi Társaság alapítását 2002. február 21-én határozták el az MTA Regionális Tudományos Bizottság tagjai. Az alapítók szándéka szerint a társaság célja, hogy

- a regionális tudomány művelőinek szakmai fórumot biztosítson;

- megismertesse és népszerüsítse a nemzetközi és hazai regionális tudomány eredményeit;

- bekapcsolódjon a regionális tudomány nemzetközi szervezeteibe, s ezzel terjessze a hazai tudományos eredményeket;

- kapcsolatot építsen ki a regionális politika alakítóival és annak gyakorlati megvalósítóival a tudományos eredmények ismertetésére, befogadására;

- támogassa mindazon kutatóhelyeket, felsőoktatási intézményeket és más szervezeteket, ahol a regionális tudományt művelik vagy a jövőben művelni kívánják;

- pályázatokkal, ösztöndíjakkal és más kezdeményezésekkel támogassa a regionális tudomány művelőit tudományos eredményeik közreadásában és népszerüsítésében;

- konferenciák, tanácskozások szervezésével, valamint könyvek, kiadványok megjelentetésével járuljon hozzá, hogy a tudományterület eredményei minél szélesebb körben megismerhetők és felhasználhatók legyenek;

- támogassa a Kárpát-medencei regionális kutatásokat, a regionális fejlődést;

- közreműködjön az Európai Unió transzregionális politikájának Kárpátmedencei megismertetésében;

Az első évtized tevékenységét értékelve megállapítható, hogy az alapcélok többségének elérése sikerült. A társaság tíz év alatt a magyar regionális tudomány szakmai fórumává vált. Az MRTT 2011 novemberében megválasztott elnöksége az alapszabályban lefektetett célok megvalósítása érdekében a következő programot dolgozta ki a 2012-2015 közötti időszakra.

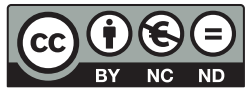


Alapelv: A társaság független civil szervezet, amely a területi kutatással, fejlesztéssel foglalkozó szakembereket fogja össze.

Kiemelt célok:

- szakmai kapcsolatok erősítése (fórumok, konferenciák, tanácskozások szervezése, nemzetközi szervezetekben való aktív részvétel);

- szakmai ismeretek megosztása, bővítése (tájékoztatás, képzés, információk biztosítása);

- véleménynyilvánítás a legfontosabb területi folyamatokat érintő politikai, gazdasági és társadalmi kérdésekben.

A regionalitás, a szélesebb értelemben vett területiség szerepének és funkciójának átalakulása a tudományos és a politikai rendszerben a jövőben nagyobb aktivitást kíván meg a szervezettől, annak tagjaitól. A társaságnak több kihívásra is választ kell adnia.

- Az MRTT stratégiai partnere az MTA Regionális Tudományos Bizottság (RTB). A két szervezet közötti munkamegosztást a közös célok áttekintésével kell kialakítani. Az MRTT bizonyos feladatait egyértelműen el kell választani az RTB, illetve más szakmai szervezetek tevékenységétől, de egyúttal szoros kapcsolatot kell kialakítani.

- Át kell gondolni az új állami felfogásban a területi szemlélet megjelenését, annak értelmezését a közigazgatás, a gazdaság- és fejlesztéspolitika, a vidék-, terület- és településfejlesztés szintjén, továbbá a társadalmi gondolkodásban és cselekvésben egyaránt.

- Elkezdődött a felkészülés az Európai Unió 2014-2020 közötti tervezési időszakára.

- Új tervezési rendszer alakul ki, amelyben a területi szemlélet megjelenése bizonytalan.

- Új témák és összefüggések jelentek meg a területi folyamatokban - klímaváltozás, helyi fejlesztés, civil társadalom, együttműködési terek stb., amelyekre reagálni kell.

- A regionális tudomány nemzetközi - elsősorban kelet-közép-európai - kapcsolatainak erősítése kívánatos, ehhez a Kárpát-medencei együttműködések kiváló alapot adnak.

- A szakterület intézményi, működési kereteiben jelentős átalakulások zajlanak (akadémiai és felsőoktatási reform). A regionális tudomány és gyakorlat, valamint annak intézményi keretei jelentősen változnak, új szervezetek (pl. tervhivatal) és szereplők jönnek létre.

- Új generáció ,jelent meg” az RTB-ben és az MRTT-ben.

Stratégiai célok (2012-2015):

- a térszemlélet társadalmasitása, a társadalom térszemléletének alakítása, erősítése, tudományos és szakmai fejlesztésének (tervezés, menedzsment) támogatása, fórumok biztosítása az ezzel kapcsolatos vitáknak, véleményeknek, eredményeknek; 
- a területiség szélesebb, árnyaltabb értelmezése következtében összefogni a területi folyamatokban érintett szakembereket, új témák és szakmai irányok felé nyitni (vidék-, település-, környezetfejlesztés);

- határozottabb szakmai véleménynyilvánitás a területi folyamatokat és intézményeket érintő nemzeti szintű kérdésekben;

- a társaság önálló szakmai arcának, imázsának kialakitása;

- bekapcsolódás az Európai Unió új tervezési időszakára való felkészülésbe, a nemzeti tervekben a területi összefüggések és intézményi, finanszírozási kereteik figyelemmel kísérése;

- a Kárpát-medencében kiépült magyar regionális tudományi mühelyek és területfejlesztési szakemberek bázisának további erősitése, és erre építve kelet-közép-európai együttmüködésének ösztönzése, alakítása;

- a regionális tudományhoz kapcsolódó felsőoktatási, doktori képzések támogatása, együttmüködési tereik szélesítése, új képzési formák támogatása (nyári egyetem, szakkollégium, szakképzés, oktatói fórumok);

- a tagsági kör szélesitése, a fiatalok (hallgatók, szakemberek) minél nagyobb körének bevonása, az ehhez kapcsolódó fórumok müködtetése;

- a területi témában is érintett szervezetekkel (Magyar Statisztikai Társaság, Magyar Urbanisztikai Társaság, Magyar Földrajzi Társaság stb.) és más szakmai tömörülésekkel (pl. vidék- és területfejlesztőkkel) való együttmüködés erősitése: közös rendezvények, fórumok, véleménynyilvánítás és kiadványok;

- a társaság múködésének biztositása (támogatások, pályázatok), új módszerek a támogatáshoz (szponzorok, konzorciumi együttmüködés).

Akciók a 2012. évben:

- a tagozatok megerősitése, újjászervezése; a határon túli és a hazai tagozatok munkájának (ön)értékelése, a tagozatvezetők megerősítése, illetve új tagozatvezető felkérése, középtávú tervek összeállítása; cél a folyamatos, önszerveződő tagozati munka, évente legalább két összejövetel/rendezvény, a tagozatok a következő vándorgyűlésen kapjanak lehetőséget tevékenységük bemutatására;

- a fiatalok bevonása a társaság működtetésébe, vezetésébe; igény esetén ifjúsági tagozat megszervezése, amelynek két képviselője az elnökségi üléseken tanácskozási joggal vesz részt;

- hírek (hírlevél) küldése a tagságnak, az RTB-vel együttműködésben;

- kapcsolatfelvétel a szakmai értelemben vett társszervezetekkel;

- együttműködési tervek, javaslatok kidolgozása a rokonszakmákkal;

- jubileumi vándorgyűlés szervezése novemberben Győrben, amelynek témája a regionális tudomány;

- Európa és a területfejlesztés szakmai mühely létrehozása: az EU kohéziós politikájának, a következő programozási időszak és a hazai tervezés, szabályozás alakulásának figyelemmel kísérése, a területi hatások értékelése, workshopok szervezése; 
- a nemzetközi kapcsolatok megerősítése, részvétel az ERSA és az RSA éves konferenciáin, intézményi tagság;

- tudományos díjak odaítélése, szabályok részletes kimunkálása;

- Horváth Gyula elnöki munkájának elismerése a jubileumi vándorgyülésen;

- véleménynyilvánitások a területi folyamatokat érintő kérdésekben (szakmai viták szervezése stb.);

- tagtoborzás, különös tekintettel a társszakmák és a fiatalabb korosztály képviselőire;

- a müködés pénzügyi hátterének biztositása: szponzorkeresés, pályázatokba partnerként, projektekbe alvállalkozóként történő bevonás, támogatások.

A programot a társaság elnöksége 2011. december 12-én jóváhagyta. 